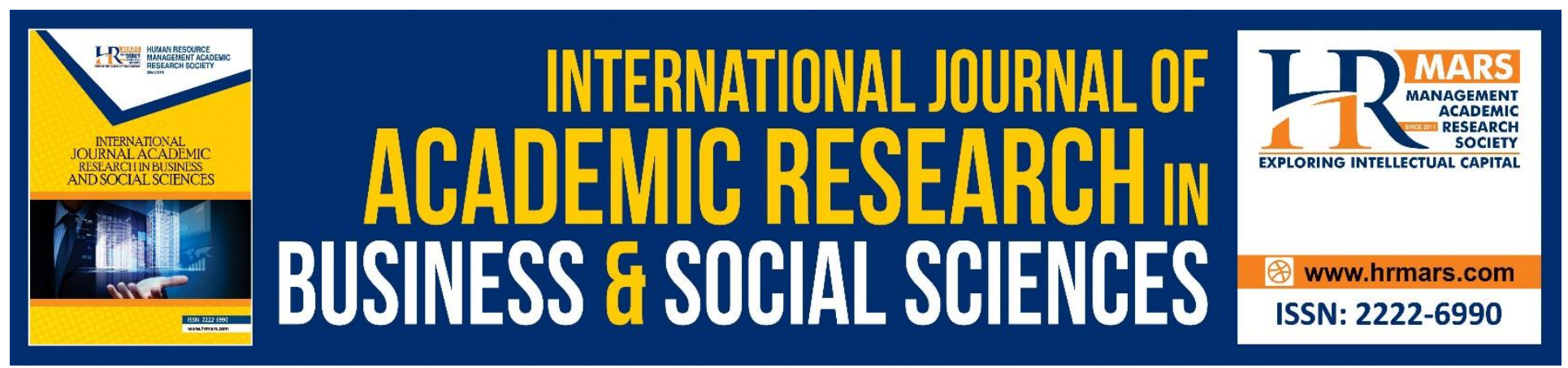

\title{
A Case Study of PERPADUAN Pre-School settings Inculcates Multi-Ethnic Awareness among Preschoolers'
}

Nordin Mamat, Abdul Rahim Razalli, Abdul Talib M. Hashim, Abdul Razaq Ahmad, Mohd Mahzan Awang

To Link this Article: http://dx.doi.org/10.6007/IJARBSS/v8-i10/5289

DOI: 10.6007/IJARBSS/v8-i10/5289

Received: 03 Sept 2018, Revised: 23 Oct 2018, Accepted: 27 Oct 2018

Published Online: 09 Nov 2018

In-Text Citation: (Mamat, Razalli, Hashim, Ahmad, \& Awang, 2018)

To Cite this Article: Mamat, N., Razalli, A. R., Hashim, A. T. M., Ahmad, A. R., \& Awang, M. M. (2018). A Case Study of PERPADUAN Pre-School settings Inculcates Multi-Ethnic Awareness among Preschoolers. International Journal of Academic Research in Business and Social Sciences, 8(10), 1181-1190.

Copyright: (c) 2018 The Author(s)

Published by Human Resource Management Academic Research Society (www.hrmars.com)

This article is published under the Creative Commons Attribution (CC BY 4.0) license. Anyone may reproduce, distribute, translate and create derivative works of this article (for both commercial and non-commercial purposes), subject to full attribution to the original publication and authors. The full terms of this license may be seen

at: http://creativecommons.org/licences/by/4.0/legalcode

Vol. 8, No. 10, 2018, Pg. 1181 - 1190

http://hrmars.com/index.php/pages/detail/IJARBSS

JOURNAL HOMEPAGE

Full Terms \& Conditions of access and use can be found at http://hrmars.com/index.php/pages/detail/publication-ethics 


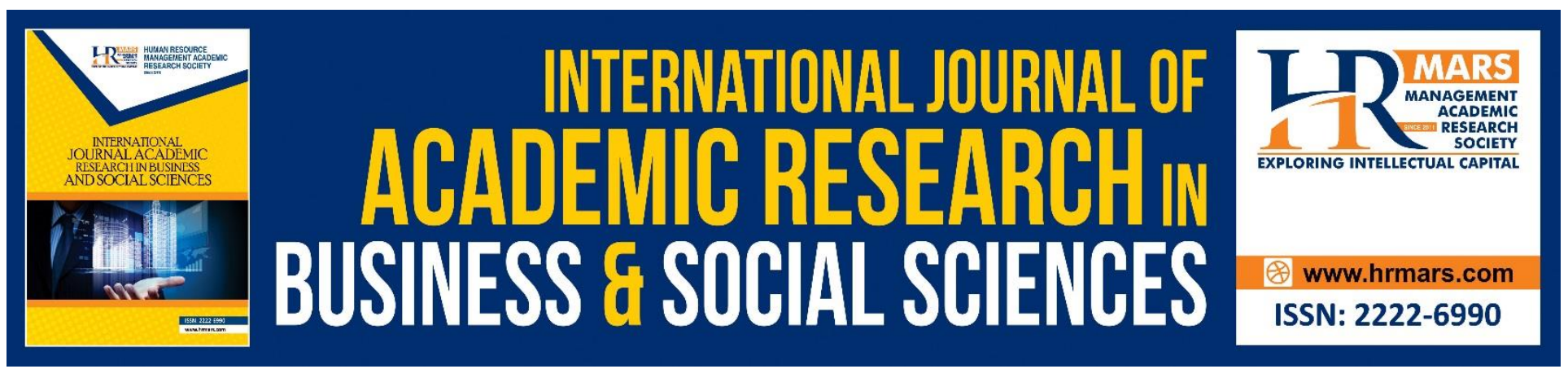

\title{
A Case Study of PERPADUAN Pre-School settings Inculcates Multi-Ethnic Awareness among Preschoolers'
}

\author{
Nordin Mamat \\ Department of Early Childhood Education, Faculty of Human Development, Universiti Pendidikan \\ Sultan Idris, Malaysia.
}

Abdul Rahim Razalli

Faculty of Human Development, Universiti Pendidikan Sultan Idris, Malaysia.

Abdul Talib M. Hashim

Faculty of Human Development, Universiti Pendidikan Sultan Idris, Malaysia.

Abdul Razaq Ahmad

Faculty of Education, Universiti Kebangsaan Malaysia.

Mohd Mahzan Awang

Faculty of Education, Universiti Kebangsaan Malaysia.

\begin{abstract}
This paper presents an overview of how children from the three different ethnic groups inculcate multi-ethnic awareness in ethnically diverse pre-school settings and how pre-school nurtured children's unity. The study involved 25 children and their teachers from one PERPADUAN Pre-school. A qualitative methodology was applied. Direct observation and in-depth interviews were conducted with the children and teachers within 16 weeks. The primary findings of this research found that the PERPADUAN Pre-school can be considered a "Mini Malaysia" because the ethnic situation in the school reflects the diversity of Malaysian society. Activities such as celebrating festivals in Malaysia based on ethnic backgrounds are held in pre-school. Finally, the PERPADUAN Pre-school ethos toward children's social development is to promote a feeling of unity and acceptance among the ethnically diverse society of Malaysia. The pre-school teacher sees that it is the responsibility of PERPADUAN Pre-school to instil the knowledge that the children need to integrate and participate in a common shared national culture, values and identity of Malaysian.
\end{abstract}


Keywords: Pre-school, Teaching and Learning, Early Childhood

\section{Introduction}

Malaysia is unique in the sense that it has multiple school streams while other countries have only one, regardless of ethnicity and language diversity. There are two main types of public primary schools in Malaysia: national (Sekolah Kebangsaan in Malay, abbreviated as SK) and national-type (Sekolah Jenis Kebangsaan, abbreviated as SJK). National-type schools are further divided into Chinese national-type schools (Sekolah Jenis Kebangsaan Cina, SJK(C) and Tamil national-type schools (Sekolah Jenis Kebangsaan Tamil, SJK (T)). The medium of instruction is Malay for SK, Mandarin and simplified Chinese Character writing for SJK(C), and Tamil for SJK(T) (Malaysia, 1990). Malay and English are compulsory subjects in all schools. All schools use the same syllabus for non-language subjects regardless of the medium of instruction. The major goals of national education policy and primary schools in Malaysia are to "inculcate and nurture national consciousness through fostering common ideals, values, aspiration and loyalties in order to mould national unity and national identity in a multi-ethnic society".

However, these school systems have been heavily criticised because it has been found that children are finding it difficult to establish friendships, get along with schoolmates from diverse backgrounds, and to have respect for each other either in the classroom or while doing extra curricular activities (Yusop, 2005). Young children are not interested in a meaningful interaction between the main races because there appeared to be some degree of negative perception and mistrust among them; the Malays, Chinese and Indians.

A large number of Chinese and Indian students could not speak Malay language well which affects their inter-ethnic social interaction. In light of this information, parents of these groups and the institutions where children have their first formal contact with others are deemed to have failed to instil in their children proper standards promoting Malaysian cultures such as language and other ethnic backgrounds. In order to understand the impact of ethnicity on children's behaviour and crossethnic relationships, I reviewed the literature in line with this study. The study of children's relationships in a multi-ethnic pre-school is important for the improvement of intergroup relations.

\section{Objectives of the Study}

The objective of this study is to examine how do children from three different ethnic groups inculcate multi-ethnic awareness in ethnically diverse pre-school settings and how pre-school nurtured children's unity.

\section{Literature Review}

Multi-ethnic pre-school refers to "pre-school that includes children of different ethnic groups, which is the policy of the pre-school itself to ensure the composition of the pre-school entrants consist of mix of Malays, Chinese, Indian and others. The aim of the multi-ethnic pre-school is to unite three dominant ethnic groups of Malaysian in order to ensure national integration" (Majzub, 2006, p. 87). Many scholars have addressed the benefits of pre-school settings for children's attention during 
INTERNATIONAL JOURNAL OF ACADEMIC RESEARCH IN BUSINESS AND SOCIAL SCIENCES Vol. 8, No. 10, Oct. 2018, E-ISSN: 222 2-6990 @ 2018 HRMARS

learning activities. Pre-school setting promote children's attention and learning at early stage. Children's participation in classroom activities is highly influenced by pre-school setting and teacher's approach (Mura et.al, 2015). According to Nordin \& Ainon (2013) direct cross-ethnic and teaching multiculturalism awareness is more effective in changing children's intergroup attitudes.

Bentley, F.D (2012) explains the meaning of multiculturalism in the early childhood classroom practices in everyday lives of four- and five-year-olds. The study examines classroom practices as children and teachers construct meaning around multiculturalism in early childhood. Through classroom research and discussion, the children develop their own concepts around these issues, finding meaningful ways to share their knowledge with the larger school community. These fundamental values can be integrated into the lives of young children especially in the early childhood classroom.

According to Chi-Hung \& Ming-Tak (2017), the practice of multicultural teaching in early childhood education are an important element of high-quality developmentally and culturally appropriate early childhood programmes. The study investigates the perceptions of teaching competency in multicultural classroom held by 347 teachers at 22 kindergartens in Hong Kong. The result indicates that preschool teachers fit with the model of multicultural teaching competency scale (MTCS) for children from ethnic-minority. The most important element of high-quality developmentally and culturally appropriate early childhood programmes is preschool teachers.

Meanwhile Buchori, S \& Dobinson, T (2015) deduct a different view; early childhood teachers view the children's previous cultural background as a burden. They are concern for the children who are not performing up to the curriculum standard and fear of not meeting their own expectations, those of the system and those of the children's parents. In the Australian Early childhood education, in order to address the needs of the children from diverse cultural background in their care, they implemented a setting of a culturally diverse classroom and pedagogic practice. This shows the teachers' understandings of the multicultural education goals. It is important to teach children about different cultures and the most effective way to do this is to emphasise points of comparison between cultures.

According to Samni Suraji, Abdul Razaq Ahmad, Mohd Mahzan Awang, Nordin Mamat \& Ahmad Ali Seman (2018), results from their study at preschool settings show a different significant on the effectiveness of Fun Learning module in enhancing patriotism among preschool children. This quasi experiment involved 1000 sample from 4 preschools under government. Treatment group involved 50 pupils from 2 classes in 2 preschools as well as controlled group. The study demonstrated that fun learning approaches are suitable for cognitive level and preschool children's interest in improving Malaysian historical values and culture via history learning at early childhood stage.

\section{A Qualitative Design}

Denzin and Lincoln (2003) emphasize that a qualitative approach allows the researcher to understand elements of behaviours by getting to know those involved, their values, beliefs, and emotions. A qualitative methodology was used in this research because it was considered to be the most appropriate way of discovering or uncovering the perceptions about children's social behaviour held by parents of different background. It was considered crucial in this research to hear personal views from Malay, Chinese and Indian ethnic background groups, because the research would contribute 
to the planning of culturally appropriate ways to improve ethnic relationships in Malaysia and to make these relationships more resilient and vibrant.

The framework for the conduct of this research includes observation, field notes, talks, interviews and documents that form the bases for ethnographic research. Since the study involved detailed qualitative research on children's social behaviour, it was impossible to cover all the preschools in depth within the 16-week period data collection. I chose one Perpaduan Pre-school for data collection and observed about 25 children. In order to cover in-depth data, I worked in Preschool every day for 16 weeks. Ethnography involves long term commitment from the researcher. I was there every day in order to build up a picture of human behaviour, working on getting to know the children and getting to know the setting so I was able to build up a 'thick description' of the setting and children's behaviour and I consider this to be ethnography. This includes observation on nature of peer interactions such as instances of quarrelling among peers, or prosocial behaviours such as comforting one another.

\section{RESULTS}

\section{PERPADUAN Pre-school As A “Mini Malaysia”}

According to the teacher, the PERPADUAN Pre-school can be considered a "Mini Malaysia" because the ethnic situation in this pre-school reflects the diversity of Malaysian society. The kind of ethnic acknowledgement mentioned brought out her emotional responses or personal thoughts. The teacher explained that,

Teacher: This pre-school is a model of "Mini Malaysia"...the communities who live here come from diverse ethnic backgrounds just like the school children. The ethnic composition here is balanced every year. We practice cultural diversity...celebrate Raya (Eid Mubarak), Tahun Baru Cina (Chinese New Year) and Deepavali. So...every child has been exposed to different cultures and the most important thing is to be sensitive towards other ethnic groups.

(Paragraph 19)

With the above race identification, the teacher personally thought that PERPADUAN Pre-school is a "Mini Malaysia" because the ethnic situation in pre-school is as diverse as in Malaysian society. The teacher explains with reference to the ethnic groups that the composition of the school is balanced. In terms of social group domination in this pre-school, the teacher explains that the "majority" positions belong to the Chinese and Malays and the minority is comprised of Indians. These ethnic group positions do not show the dominant social groups. The above statement provides evidence for the practice of cultural diversity among the children in the classroom, especially during festive celebrations. The teacher exposes the children to the cultures of every ethnic group to ensure they have sensitivity towards them. The teacher added:

Teacher: I have observed from 20 years ago this pre-school is always an indicator as a reference for the government to show a multi-ethnic society. It is not only the Department of Unity and Integration but other departments such as Department of Health to conduct clinical research here.

(Paragraph 26) 
INTERNATIONAL JOURNAL OF ACADEMIC RESEARCH IN BUSINESS AND SOCIAL SCIENCES

Vol. 8, No. 10, Oct. 2018, E-ISSN: 2222-6990 ㄷ 2018 HRMARS

It is not surprising that this PERPADUAN Pre-school is a model of the multi-ethnic pre-school and has become a reference for the Department of National Unity and Integration and other departments in Malaysia.

\section{Greetings and Respect}

Based on the PERPADUAN Pre-school documents, and observations, the aims of PERPADUAN Pre-school are to be a centre for the parents and the government agency to transfer national values to the children. It is a transmitter towards ethnic diversity and a symbolic act of keeping the national flag waving for the children via the explanation of government policy towards a multi-ethnic community. For example,

The teacher teaches about respect, respecting teachers and parents have all become good habits for the children when they greet the teachers. Children get teacher's hand and kiss it.

(Observation: Morning Session Episode [12 June 2017]).

Indeed, in Malay culture the children also kiss their teacher's hand as a symbol of respect when they meet and leave school.

This pre-school concept is based on religious tolerance, which respects other religions even though Islam is the official religion in the country. Everyday rituals like saying Selamat Pagi and Salam Sejahtera in Malay instead of Arabic before classes start, after that recites the dua before having breakfast and tea time become meaningful acts for all ethnic groups. The dua prayer is specific for all ethnic groups such as dua for good health, thanks to God (this does not only refer to Allah [God in Arabic] (Observation: Meal Time Episode [16 June 2017]). The use of the word Allah may be sensitive for parents who are Hindu or Buddhist.

According to the teacher, based on her observation of more than 20 years that has been teaching in this PERPADUAN Pre-school, she stated;

"transmitting positive cultural and religious tolerance are of utmost importance in order to guarantee a harmonious community. Each ethnic group in this pre-school community respects the culture and beliefs of other ethnic groups... and one should not be limited to the shallow thinking of one's ethnic culture and religion as the only one that is right and perfect. This pre-school shows responsibility to develop the children's mindset to respect other religions. Every ethnic group has its own rituals, which fosters religious tolerance towards other religions, whether Muslim or nonMuslim. The data from observation explain same issues, for example:

There were five Indian children wearing the pottu marks. Pottu is a round mark on the forehead (between the eyebrows). The children also wore black bracelets around their wrists to ward off disaster. A type of string (black or red) that has been recited with spell is worn.

(Observation: Morning Session Episode [26 June 2017])

When I asked a response from the teacher about this issue, she replied

"I have explained to the class [children] that religious practice is a sensitive subject, they [children] do not make jokes about that".

(Observation: Informal Response Episode [26 June 2017]) 
INTERNATIONAL JOURNAL OF ACADEMIC RESEARCH IN BUSINESS AND SOCIAL SCIENCES

Vol. 8, No. 10, Oct. 2018, E-ISSN: 222 2-6990 @ 2018 HRMARS

According to the Hindus, pottu is a third eye of wisdom. To open an eye of wisdom is one of the motives in life (souls) any individual should achieve.

\section{Variety of Food and Dress}

A part of the effort by the National Unity and Integration Department includes the ethos of this pre-school which aims to strengthen awareness and positive tolerance that has been inherited by the Malaysian community. The PERPADUAN Pre-school takes the responsibility to combine the three ethnic cultures and beliefs as Malaysian culture. This can be seen in all the activities that are held, like cultural festivals, religious celebrations and ethnic ceremonies. Pre-school children are exposed to these activities. During the celebrations, the children wear their traditional dress: baju Melayu and baju kurung for the Malay children or cheongsam for the Chinese children, while the Indian children wear their sari and dhoti (Document: School Presentation). This pre-school is a place for the children to learn about each other's cultures and the culture of any other ethnic group that is practised in the country.

The pre-school aims to develop the mindset of children by sharing norms and values from different backgrounds. A tolerant attitude among the children can be seen by the recognition and acceptance of culture among them and the respect shown to each other. I observed the community here sharing the same values and viewpoints beyond their ethnicities. These things help the community to develop cross-cultural relationships although their backgrounds differ in aspects such as culture, language and religion. The sharing of values and norms in a multicultural society can be seen in the community cooperation activity which is their priority for integration and harmony. Their relationship is based on their community, not their ethnic group per se. Ethnic sentiments and religion are not important factors between the ethnic groups. For example, they get used to ethnic foods such as nasi lemak (rice with coconut milk) from the Malay culture and roti canai (paratha) from the Indian culture or even using chopsticks. The pre-school activities show the children's open-minded attitude towards culture.

\section{Celebrating Festivals}

According to the teacher, the following activities; celebrating festivals in Malaysia based on ethnic backgrounds are held in pre-school as part of the annual ceremonies in all pre-schools under the Ministry of the Prime Minister. For example, the celebration of "Hari Raya" (Eid Mubarak) for Malays, Chinese New Year for Chinese and "Deepavali" for Indians were together held in pre-school in 2008. The Malaysian government recognises these as national holidays and declared a public holiday on those days. Hence, after the celebration, the teacher arranges with children and parents to celebrate the festival at the school in order for children from different ethnic backgrounds to experience the situation and environment of every festival celebrated by Malays, Chinese or Indians. The main objective is to integrate Malaysia and a multi-cultural approach is being developed. For example, as a preparation to celebrate Deepavali, the school is decorated with "a row of lamps", with foods like "kuih batu", "maruku" and others. There are similar celebrations for "Hari Raya" and Chinese New Year which come up with various decorations and foods. During the celebrations, the children wear their traditional dress for example "baju Melayu" and "baju kurung" for the Malay for the Chinese children whilst the Indian people wearing "sari" and "dhoti". According to the teacher, these three 
celebrations are held in pre-school once a year after the celebration with full preparation that involves children and their parents as a part of PERPADUAN Pre-school niches. This explanation is based on the document from the teacher's report and pre-school yearly report which is documented in the pre-school video and summary in the Annual Report to the Department of Integration and National Unity.

According to Mrs Mona's view about the impact on pre-school children exposed to other cultures:

Mrs Mona: I think mostly the teacher will take into account the multi-ethnic background. For example, during the three main ethnic festival celebrations my child knows... when and what other people will wear and eat. The pre-school also inculcates social relationships between my son and children from other ethnic groups.

(Paragraph 61)

The statements above also suggest a tendency towards tolerance of both ethnicities and cultural diversity in PERPADUAN Pre-school during celebrations and inculcating social relationship. From my observation, I would say it has a genuine impact on the children because they understand what and when the celebration is described. Here is a response from a child regarding a celebration they experienced at school:

I love to play with Malay friends ... during "Malay raya" (Eid Mubarak) we meet together....

We went to our neighbour's house because it is near to our house ... we eat "ketupatrendang" (rice with beef)

(Interview Child 16)

The above statement demonstrates that the environment has developed true understanding about the festival's children celebrate. The impact from school activities is translated into the children's actions, therefore nurturing the sense of belonging and developing a good friendship.

\section{Discussion and Conclusion}

PERPADUAN Pre-school can be considered a "Mini Malaysia" based on the ethnic situation in the school which reflects the diversity of Malaysian society. With reference to the composition of children from multi-ethnic groups, cultural diversity is practised among the children in the classroom, especially during festive celebrations. This pre-school is a centre for the government agency to transfer the national values to the children; transmitting positive cultural and religious tolerance is of utmost importance in order to guarantee a harmonious community. The teacher has exposed the children with the cultures of every ethnic group to ensure they have the sensitivity towards other ethnic groups. This PERPADUAN Pre-school is a model of a multi-ethnic pre-school and has become a reference for the Department of National Unity and Integration and other departments in Malaysia. Therefore, the pre-school ethos works in line with the behaviour accepted by the parents and community, and this is consistent with findings from Corsaro and Molinari (2000) on the types of priming events in the pre-school in which children participate and attend prospectively to on-going or anticipated in activities have changed their lives. They identify different types of priming events in pre-school and show how collective activities in these events affect the children's representations (p.16). I found that different types of priming events involving children's collective and practical 
activities with others in the pre-school setting such as seating formation, school routines and rituals, are crucial in priming children's behaviour.

The PERPADUAN Pre-school was founded to inculcate integration values and ideas towards national unity for the three major ethnic groups as targeted for every child. The aims include the need to integrate or assimilate the children and to get them ready and familiar with the concepts, information, language and values required by a multi-ethnic society. In this case, in the teacher's point of view, the pre-school activities are important for the children in a multi-ethnic pre-school in order for them to understand and accept the heterogeneous ethnic groups and social structures of the wider society. Several activities that are central to this approach are worthy of mention here.

Another issue concerning the setting of the pre-school is the use of materials which represent the ethnic groups. The surrounding of the pre-school setting is made up of materials which represent the ethnic groups and this provides a climate of Malaysian culture for the children and gives them a psychological message that affects awareness of multicultural society. The features of the pre-school materials totally stimulate and inculcate national unity values. This study is consistent with studies by Majzub (2006) and Prochner, Clegmen \& Green (2008) who examined the way the pre-school space is constructed and used with reference to pedagogical materials. Materials are described as an element of the spatiality of pre-school, their meaning constructed from the interaction between physical and social forces, and which cultivated the children's aesthetic sense and self-confidence (Prochner, et al., 2008, p. 190). Materials in the pre-school space encourage the children's interactions. It depends in what way the pre-school materials and environment reflect the three ethnic backgrounds. This includes the design of the building, its location in the community, the people, materials, and furnishings within it.

\section{Corresponding Author}

Nordin Mamat

Department of Early Childhood Education, Faculty of Human Development Universiti Pendidikan Sultan Idris, Malaysia.

Email: nordin@fpm.upsi.edu.my

\section{References}

Corsaro, W. A. (2005). The sociology of childhood (2 ed.). London: Sage Publications.

Bentley, F. D. (2012). Rights are the Words for Being Fair: Multicultural Practice in the Early Childhood Classroom. Early Childhood Education Journal. Vol 40:195-202.

Buchori, S. \& Dobinson, T. (2015). Diversity in teaching and learning: Practitioners' perspectives in a multicultural early childhood setting in Australia. Australasian Journal of Early Childhood Vol. 40 (1):71-79.

Chi-Hung, L. \& Ming-Tak, H. (2017), Understanding and Enhancing Multicultural Teaching in Preschool. Early Child Development \& Care. Vol. 187(12):2002-2014.

Denzin, N. K., \& Lincoln, Y. S. (2003). Collecting and interpreting qualitative materials. Newbury Park Sage. 
Majzub, R. M. (2006). The inculcation of National Integration through pre-school education: A case of Tabika Perpaduan Negara. In Z. Hassan, A. L. Samian \& A. D. Silong (Eds.), Reading on ethnic relations in a multicultural society. Serdang: UPM Press.

Mura, G., Vellante, M., Nardi, A. E., Machado, S. \& Carta, M. G. (2015). Effects of school-based physical activity interventions on cognition and academic achievement: A systematic review. CNS and Neurological Disorders - Drug Targets. 14(9). 1194-1208.

Mamat, N. \& Omar, A. (2013). Culturally responsive pre-school education: Interaction among children from cross-ethnic groups in a multi-ethnic preschool. International Journal Early Childhood Education and Care, 2, 67-86.

Suraji, S., Ahmad, A. R., Awang, M. M., Mamat, N. \& Seman, A. A. (2018). Fun learning Approaches in Enhancing Patriotism Values among Preschool. International Journal of Academic Research in Business \& Social Sciences. Vol. 8 (8) 152 - 158. 